\title{
МІСЦЕ І ЗНАЧЕННЯ СЕЛЕНОВМІСНИХ ПРЕПАРАТІВ У ЛІКУВАННІ АВТОІМУННОГО ТИРЕОЇДИТУ
}

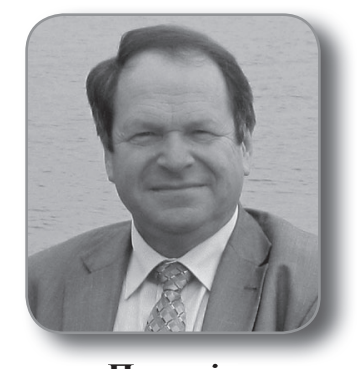

Паньків

Володимир Іванович д. мед. н., проф.

зав. відділу клінічної тиреоїдологіі 01021, м. Київ, Кловський узвіз, 13-А e-mail: vipankiv@mail.ru

\author{
B.I. Паньків \\ Украӥнський науково-практичний цеентр ендокринної хірургії, \\ трансплантації ендокринних органів і тканин МОЗ України, \\ м. Kü̈в
}

Хронічний автоімунний (лімфоматозний) тиреоїдит (AIT) описаний японським хірургом Х. Хашимото в 1912 році. Вивчаючи гістологію щитоподібної залози (ЩЗ), видаленої у чотирьох хворих з дифузним зобом, вчений установив зміни специфічної морфологічної будови залози з обов'язковою наявністю характерних ознак (дифузна інфільтрація ЩЗ лімфоцитами, специфічне утворення лімфоїдних фолікулів, деструкція епітеліальних клітин і проліферація фіброзної тканини, яка заміщує нормальну структуру ЩЗ).

Хронічний AIT у стані еутиреозу або гіпотиреозу - одне з найчастіших захворювань ЩЗ, яким страждає понад 10\% жінок і 2\% чоловіків. Запропоновано декілька гіпотез патогенезу цього захворювання. Також існують генетичні передумови до розвитку AІT. На частоту AIT впливають чинники довкілля (споживання йоду, прийом імунотерапевтичних засобів, вірусні інфекції, які можуть ініціювати захворювання). Наявність антитіл до тиреоїдної пероксидази (ТПО) спостерігається у 10\% випадків практично здорових дорослих жінок і у 5\% практично здорових чоловіків (N. Amino).

Відсутність на сьогодні патогенетичної терапії AIT на ранніх стадіях його розвитку не може бути підґрунтям для заперечення наявності самого захворювання. Справді, в арсеналі лікаря поки що немає препаратів, 3 допомогою яких постає можливість впливу на початкові стадії автоімунного процесу. Однак, спостерігаючи за прогресом досліджень останніх років у галузі імунології і молекулярної біології, слід очікувати розробки нових методів і лікарських препаратів, які 6 дозволили активно впливати на стабілізацію найбільш ранніх проявів розвитку і навіть на профілактику автоімунних захворювань, включно 3 AIT.

Специфічної терапії AIT на сьогодні не існує. За наявності тиреотоксичної фази AІT доцільне призначення симптоматичних засобів (бета-блокатори, седативні та ін.) у більшості випадків без використання тиреостатиків. При явищах гіпотиреозу призначають препарати гормонів ЩЗ. У той же час питання про доцільність застосування цих засобів при AIT в стані еутиреозу залишаються дискусійними. У минулому рекомендувалося призначення глюкокортикоїдів у досить великих дозах з метою впливу на автоімунні процеси, особливо на гуморальний імунітет. На сьогодні чітко встановлена неефективність використання кортикостероїдів при AIT.

Враховуючи, що автоімунна агресія на сьогодні визнана ключовим чинником, що призводить до деструкції тиреоїдної тканини 3 неминучим подальшим розвитком гіпотиреозу, вплив на автоімунний процес є суттю патогенетичної терапії AIT.

Результати фундаментальних досліджень 3 біохімії, молекулярної фармакології і клінічної медицини дозволяють стверджувати, що при здійсненні профілактики та лікування захворювань щЗ та інших йододефіцитних станів слід враховувати нерозривний зв'язок обміну йоду в організмі 3 метаболізмом інших мікроелементів - насамперед селену як основного молекулярного синергіста йоду, що має важливе значення у функціонуванні Щ3 [Jaminet P., 2011].

На сьогодні доведено, що дефіцит селену належить до чинників розвитку захворювань 
щ3. Зниження рівня селену в сироватці крові асоціюється з такими патологічними змінами в Щ3, як збільшення ії об'єму, наявність гіпоехогенності ультрасонографічної ознаки лімфоїдної інфільтрації Щ3, вузлових або колоїдних утворень [Derumeaux H. et al., 2003].

Крім того, селен бере участь в антиоксидантному захисті тиреоцитів та активації тиреоїдних гормонів, регулює процеси апоптозу. Експериментальними дослідженнями доведено, що навіть за умов адекватного надходження йоду в організм тривалий дефіцит селену призводить до некрозу і фіброзу Щ3 [Jaminet P., 2011]. Важливість селену для ендокринної системи визначається тим фактом, що багато тканин залоз внутрішньої секреції мають механізми підтримання його належної концентрації навіть за умов тяжкого дієтичного дефіциту селену [Гмошинский И.В., Мазо В.К., 1999].

Біологічні ефекти селену на ендокринну систему проявляються шляхом експресії близько 30 селенопротеїнів, активним центром яких $\epsilon$ селен. Механізми впливу більшості селенопротеїнів на функцію щ3 розшифровані відносно нещодавно. Так, йодтиронін-5-дейодиназа активує процес перетворення тироксину в трийодтиронін, тироксин-редуктаза каталізує НАФ-залежну реакцію відновлення тироксину, цитолітична глутатіонпероксидаза здійснює антиоксидантний захист клітин від негативного впливу перекису водню, селенопротеїн N сприяє перенесенню і зниженню концентрації перекису водню, позаклітинна тромбоцитарна глутатіонпероксидаза володіє протизапальним, імуномодулюючим впливом, фосфоліпід-глутатіонпероксидаза інгібує окиснення фосфоліпідів, регулює процес апоптозу, тіоредоксинредуктаза регулює процеси клітинної проліферації, підтримує окисно-відновний баланс клітини, селенопротеїн Р здійснює транспорт селену та антиоксидантний захист [Bates J.M. et al., 2001; Schomburg L., 2011; Rayman M.P., 2012].

Одна з причин неможливості повної ліквідації захворювань, спричинених нестачею йоду, шляхом лише йодної профілактики полягає в тому, що дефіцит селену обумовлює зниження синтезу ферментів, які беруть участь в активації і регуляції балансу тиреоїдних гормонів. Додатковий прийом йоду не в змозі компенсувати цей дефект. Отримані нещодавно дані пояснюють, чому в експериментальних дослідженнях із селеновою недостатністю знижувалася конверсія тироксину в трийодтиронін з подальшим розвитком симптомів гіпотиреозу [St. Germain D.L. et al., 2005]. Враховуючи механізм дії дейодиназ, можна дійти висновку, що прийом левотироксину з метою ліквідації дисбалансу тиреоїдних гормонів на тлі дефіциту селену буде менш ефективний, оскільки селен потрібний для периферичної активації тироксину [Хохлова Е.А., 2013].

За умов дефіциту селену посилюється цитотоксична дія перекису водню, як побічного продукту синтезу тиреоїдних гормонів, на тканину ЩЗ. Вплив цього патологічного чинника може провокувати зростання титру антитиреоїдних антитіл (до тиреоїдної пероксидази, тиреоглобуліну) і зрештою призводити до розвитку автоімунних тиреопатій. У багатьох дослідженнях було проаналізовано довгострокові результати йодної профілактики за допомогою йодованої солі без ліквідації дефіциту селену [Emral R. et al., 2006].

B італійському дослідженні проведений аналіз 15-річного (1995-2010рр.) здійснення йодної профілактики у 1148 осіб [Aghini Lombardi F. et al., 2013]. Спостерігалося достовірне зниження поширеності дифузного зоба (10,3\% у 2010 р. проти 34,0\% у 1995 р.), функціональної автономії щ3 (0,5\% проти 2,5\%), гіпертиреозу (1,4\% проти 4,5\%). Однак виявлення в сироватці крові автоантитіл до щЗ (19,5\% проти 12,6\%, p < 0,0001) і поширеність АІT (14,5\% проти 3,5\%; p < 0,0001) були частішими у 2010, ніж у 1995 році.

Більшість фахівців розцінюють селен як доповнюючу ланку для успішного лікування i профілактики тиреопатій, пов'язаних з дефіцитом йоду [Turker O. et al., 2006]. Додатковий прийом селену у фізіологічних дозах до 75 мкг/добу впродовж 6-12 місяців асоціюється 3 достовірним зниженням титру антитиреоїдних антитіл (до ТПО), сприяє пригніченню автоімунного процесу і поліпшенню ехогенної структури за даними УзД. Поєднаний прийом йоду і селену дозволяє зменшити ризик розвитку AIT i рекомендований Європейською тиреоїдною асоціацією (ЕTА) з метою повноцінної йодної профілактики за умов природного дефіциту йоду [Hennemann G., 2004].

Сліпе плацебо-контрольоване проспективне дослідження, проведене R.Gartner і співавт. (2002), показало, що застосування селену у вигляді селенату натрію у добовій дозі 200 мкг (2,53 мкмоль/л) впродовж трьох місяців у хворих на АІТ супроводжується статистично вірогідним зниженням концентрації антитіл до ТПО ( $p=0,013$ ) порівняно з групою хворих, які отримували плаце$6 о$ ( $p=0,95)$. Вміст ТТГ, вільних тироксину і трийодтироніну в сироватці крові обох груп залишався без змін. 
В іншому рандомізованому плацебо-контрольованому проспективному дослідженні протягом трьох місяців вивчався вплив препарату селенметіоніну у добовій дозі 200 мкг або плацебо в поєднанні з левотироксином (у дозах, необхідних для підтримання ТТГ крові в межах 0,3-2,0 мОД/л) [Duntas L.H. et al., 2003]. У хворих на AIT, які отримували селеновмісний препарат, рівень антитіл до ТПО через 3 місяці знизився на 46\% ( $<<0,0001)$, а через 6 місяців - на 55,5\%. У хворих, які отримували плацебо, зниження відповідних показників становило 21\% через 3 місяці і 27\% - через 6 місяців.

Отже, препарати селену володіють імуномодулюючою дією і можуть призначатися хворим на AIT в поєднанні з левотироксином у випадку наявності явищ гіпотиреозу або без левотироксину у вигляді монотерапії.

Автори справедливо вказують, що препарати селену також показані пацієнтам 3 іншими автоімунними захворюваннями, зокрема дифузним токсичним зобом і цукровим діабетом 1 типу.

Україна, як континентальна держава, зазнає постійного впливу дефіциту селену в ґрунті [Караченцев Ю.І. та ін., 2013]. У сільському господарстві використовуються синтетичні добрива на основі сірки і фосфору, які ще більше збіднюють ґрунт за вмістом селену. Тому ліквідувати дефіцит цього мікроелемента за допомогою продуктів харчування практично неможливо.

За рекомендацією Food and Drug Administration (Управління з контролю якості харчових продуктів і медикаментів, США), організм дорослої людини потребує в середньому 70 мкг/добу селену (для чоловіків) і 55 мкг/добу (для жінок). Більшістю дослідників споживання до 350-400 мкг селену розглядається як безпечна добова доза.

Згідно з даними дослідження, проведеного Європейською організацією по сприянню профілактиці раку в 10 країнах Європи, показник рівня селену в сироватці крові перебував у межах 63-100 мкг/л (при нормі 120 мкг/л), що відповідає помірному дефіциту селену на європейському континенті [Thorling E.B. et al.]. Дослідження цього питання, проведені на регіональному рівні, підтвердили дефіцит селену у Волинській, ІваноФранківській, Сумській, Чернігівській і Київській областях. Проблема полягає також у вкрай низькій інформованості населення про існування дефіциту селену і його наслідки в плані впливу на функцію Щз і організм загалом.

Поєднаний дефіцит йоду і селену посилює проблему йодної недостатності в Україні, що знаходить своє відображення в структурі захворюваності Щз на сьогодні спостерігається збільшення частоти не лише гіпертрофічних і гіперпластичних процесів в Щ3, а й автоімунних тиреопатій [Чернобров А.Д., 2010]. На Прикарпатті вивчалися особливості перебігу вагітності на тлі автоімунної тиреопатії і природного дефіциту йоду. Вперше було встановлено, що у вагітних прийом препаратів йоду в дозі 200 мкг/добу призводить до очікуваного збільшення екскреції йоду з сечею, але без досягнення вірогідного клінічного ефекту. Доведено, що підвищений рівень антитіл до ТПО $є$ чинником високого ризику розвитку ускладнень вагітності. Розроблений алгоритм тактики ведення вагітних 3 підвищеним титром антитіл до ТПО і загрозою переривання вагітності за умов йодної ендемії на тлі автоімунних тиреопатій і природного дефіциту йоду із включенням препаратів йоду і селену [Тимків І.С., 2007].

Отже, поєднаний дефіцит йоду і селену посилює порушення функції ЩЗ, що виникає на тлі йодної недостатності. При цьому Україна залишається в числі тих країн, де розв'язання цього питання відсутн $\epsilon$ на державному рівні.

Щ3 належить до органів, в яких відзначається найвищий рівень вмісту селену на 1 г тканини. Селен необхідний для формування, активації $\mathrm{i}$ метаболізму тиреоїдних гормонів. Він також входить до складу низки ферментів, зокрема глутатіонпероксидаз, основна функція яких поляга $\epsilon$ в захисті людського організму від токсичної дії ендогенних або екзогенних пероксидів.

У земній корі міститься 1,10-5\% (0,1рpm) селену. Рівень його в основних тканинах і біологічних рідинах організму людини незначно перевищує це значення [Bedwal R.S. et al., 1993].

За умов дефіциту селену в організмі знижується його рівень у крові, але ще раніше знижується активність Sе-глутатіонпероксидази (GPx) - одного 3 основних антиоксидантних ферментів. Селен необхідний для регенерації цього ферменту [Саноцкий И.В., 2001]. Крім того, знижуються рівні селеновмісних білків, що зумовлює необхідність ощадливого використання цього мікроелемента. У головному мозку, репродуктивній та ендокринній системах упродовж певного часу підтримується стабільний вміст селену за рахунок його перерозподілу в організмі [Bebne D., 1995]. При подальшому зниженні рівня селену розвивається селенозалежна ендокринна і гінекологічна патологія [Тутелян В.А. та ін., 2002]. Цей феномен іменується як «жертва репродукції». Організм 
намагається зберегти себе як життєздатну одиницю, а репродуктивне надзавдання тимчасово відключається.

Селен надходить до організму у вигляді селеновмісних амінокислот - селенметіоніну та селенцистеїну [Zagrodzki P. et al., 2001]. Неорганічні сполуки селену швидко виводяться 3 організму, не досягаючи токсичного порогу [Громова O.A., 2005].

Селен володіє вагомим впливом на імунні функції. Дефіцит селену супроводжується зниженням імунної компетентності, при цьому спостерігаються порушення як клітинного імунітету, так і функції В-клітинних елементів. Це може бути пов'язано з тим, що селенозалежні ферменти, GPx i тіоредоксинредуктаза (TxR) мають антиоксидантні властивості. Вони знижують продукцію вільних радикалів, перекису водню і пероксидів жирів і фосфоліпідів. За умов дефіциту селену концентрація проміжних гідропероксидних продуктів метаболічних циклів циклооксигенази і ліпоксигенази знижується, що призводить до зменшення утворення прозапальних простагландинів і лейкотрієнів. Крім того, GPx i TxR пригнічують утворення супероксидів.

Три відомі дейодинази також належать до селенозалежних ферментів. Їх активність, на відміну від GPx, лише зменшується на тлі тяжкого дефіциту селену. Внаслідок цього концентрація тироксину в плазмі зростає, а прийом селену призводить до зниження рівня тироксину і підвищення трийодтироніну.

За умов фізіологічного надходження селену 3 їжею $(0,1-0,3$ ppm) та нормального забезпечення сіркою ефективність селенметіоніну, селеніту та селенату як джерела для синтезу селенопротеїнів однакова. Однак якщо рівень вживання селену $\epsilon$ низьким (менше ніж 0,05 ppm) або організм недостатньо забезпечений метіоніном, ефективність неорганічного селену $є$ вищою, ніж селенометіоніну [Sunde R.A., 1990].

Для синтезу гормонів Щ3 необхідна йодизація тиреоїдних залишків на тиреоглобуліні, запаси якого містяться у фолікулах залози. Йодизація каталізується тиреоїдною пероксидазою (ТПО) i потребує високої концентрації перекису водню, що потенційно небезпечно для тиреоцита. У свою чергу, утворення перекису водню регулюється ТТГ через низку взаємодіючих вторинних месенджерів [Kimura T. et al., 1995]. Йодизація тиреоглобуліну i генерація перекису водню відбуваються на поверхні апікальної мембрани тиреоцита, що забезпечує їх подальшу участь в реакціях йодизації. Надмірна кількість перекису водню, що дифундує в тиреоцит і має пошкоджуючу дію, знижується внутрішньоклітинними селеновмісними GPx, TxR та каталазними системами [Ekholm R. et al., 1998]. Активність GPx регулюється рівнем продукції супероксиду аніон-радикалу (кисню) та перекису водню [Demelash A. et al., 2004]. GPx забезпечують додаткові механізми контролю синтезу тиреоїдних гормонів шляхом регуляції концентрації перекису водню у фолікулі. При підвищенні продукції тиреоїдних гормонів надходить сигнал у ТТГрецептори, зменшується синтез перекису водню на апікальній мембрані, змінюється секреція GPx і обмежується деградація пероксиду. Цитотоксична дія перекису водню на тиреоцит включає каспазозалежний апоптоз, що відбудовується при такій концентрації перекису водню, яка $€$ недостатньою для некрозу. За умов дефіциту селену апоптотична здатність перекису водню зростає. При адекватному надходженні селену внутрішньоклітинні GPxта TxR-системи захищають тиреоцити від цих пероксидів [Howie A.F. et al., 1998].

Встановлено, що всі три дейодинази, які конвертують тироксин у трийодтиронін, містять селеноцистеїн. Тому продукція активного тиреоїдного гормону залежить від адекватного забезпечення селеном. Селеновмісні йодтироксиндейодинази присутні в більшості тканин і забезпечують механізм регуляції активації тиреоїдних гормонів [Köhrle J., 2000]. Тіоредоксинредуктази разом із НАДФ формують протекторну систему проти оксидативного стресу. Ця система також включена в інші функції клітин, у тому числі інгібування апоптозу [Rundlof A.K. et al., 2004].

Отже, у значній кількості публікацій вказується на наявність взаємодії між забезпеченням організму селеном і функцією ЩЗ. Селен - важливий компонент дейодиназ, що конвертують тиреоїдні гормони як у периферичних тканинах, так і в ЩЗ. Встановлено також, що адекватне забезпечення селеном впливає і на продуктивність синтезу тиреоїдних гормонів в Щ3, і на гіпофізарну регуляцію активності цього процесу [Turker O. et al., 2006].

P. Zagrodzki та співавт. (2008) дослідили тиреоїдний та репродуктивний гормональний стан, рівні антитіл до ТПО, а також селену та GPх у жінки віком 23 роки з AIT, яка отримувала левотироксин у дозі 25 мкг/добу (з метою підтримання ТТГ на нормальному рівні) та селен протягом 14 місяців, у тому числі перші 8 місяців по 50 мкг/добу, у наступні 6 місяців - по 100 мкг/добу. Початкові дані хворої 
свідчили про еутиреоїдний стан, рівень селену у сироватці крові становив 1,4 $\mu \mathrm{M} / \mathrm{L}$, активність GPx - 309 U/L. Упродовж періоду прийому селену його рівень у сироватці крові підвищився на 45 \%, GPx у плазмі - на 21\%. Це супроводжувалось зниженням рівня антитіл до ТПО на 76\%. Рівні тиреоїдних та статевих гормонів перебували у межах референсних норм. Після відміни селенотерапії спостерігалося зниження рівнів селену та GPx та зростання рівнів антитіл до ТПО.

Результати досліджень свідчать, що селен має імунотропну дію, механізм якої пов'язують із його здатністю активувати гени, кодуючі прозапальні цитокіни [Maehira F. et al., 2003]. R. Negro et al. (2005) продемонстрували, що призначення селену жінкам з наявністю підвищеного рівня антитіл до ТПО упродовж та після вагітності знижує активність запалення в Щ3, зменшує гіпоехогенність залози при УзД, знижує частоту післяпологової тиреоїдної дисфункції та гіпотиреозу.

Антиоксидантний ефект притаманний багатьом вітамінам і різним мікроелементам. Активність токоферолів відновлюється вітаміном С, як i активність системи глутатіону. Зазначені вітаміни і мікроелементи, атакожполіфеноли (біофлавоноїди), альфа-ліпоєва кислота і бета-каротин, діють в комплексі і формують антиоксидантний резерв клітин, що визначає їх резистентність до вільнорадикального ушкодження. Дефіцит незамінних сполук, що належать до цієї системи, пов'язаний 3 розвитком багатьох захворювань на тлі клітинного окисного ураження [Kryukov G.V. et al., 2003].

На фармацевтичному ринку України представлений збалансований антиоксидантний комплекс ОксиЛік (виробництво компанії Wörwag Pharma, Німеччина) - синергідна комбінація антиоксидантів в дозах, що відповідають фізіологічній потребі. До складу препарату входять вітаміни E і C, лікопін, бета-каротин, селен, а в числі допоміжних речовин - гліцерол і лецитин. Одна капсула препарату містить 300 мг вітаміну С, 36 мг вітаміну E (природного походження токоферол, дистилят з рослинної олії), 2 мг провітаміну А (диспергований бета-каротин), 50 мкг природного селену (у вигляді дріжджів), 2 мг лікопіну (каротиноїду 3 екстракту томатів). Усі компоненти комплексу перебувають в емульгованому стані в оточенні есенціальних фосфоліпідів, поміщені в желатинову капсулу, яка легко розпадається в кишечнику. Препарат створений за високотехнологічною фармацевтичною методикою, що значно підвищує всмоктування його компонентів в шлунково-кишковому тракті. Хелатований біологічний або органічний селен у комплексі з амінокислотами - цистеїном і метіоніном (повна копія селеновмісного пулу амінокислот-переносників селену в організмі) швидко засвоюється і втягується в біохімічні процеси синтезу селеновмісних білків і антиокисних ферментів. За своєю суттю селен-метіонін і селенцистеїн $\epsilon$ так званими ортомолекулярними речовинами, а не генетично незнайомими нашому організму ксенобіотиками. Для всмоктування та елімінації генетично знайомих нам речовин існує відлагоджена в поколіннях система всмоктування і виведення. Це дозволяє швидко поповнювати лабільний пул селену в організмі, а надлишку - безперешкодно виводитися [Чурсина Т.Я., Михалев К.А., 2010]. ОксиЛік оптимально збалансований щодо селену - 50 мкг у капсулі.

ОксиЛік володіє низкою інших позитивних властивостей: кардіо- та онкопротекція, сповільнення процесів старіння організму та ін. Препарат зручний у застосуванні за рахунок одноразового прийому на добу. ОксиЛік належить до групи патогенетичних засобів у лікуванні автоімунного тиреоїдиту і призначається по 1 капсулі щоденно впродовж одного місяця з подальшою перервою 20-30 днів. Рекомендується проведення двох-трьох курсів лікування на рік.

Отже, препарати селену володіють імуномодулюючою дією і рекомендуються в комплексній терапії AIT в поєднанні з левотироксином у випадку наявності явищ гіпотиреозу або без левотироксину у вигляді монотерапії.

\section{ЛITЕРАТУРА}

1. Гончарова О.А., Прилуцкий А.С. Роль препаратов селена в терапии аутоиммунного тиреоидита // Здоровье Украины. Тиреоидология. - 2012. - № 2 (69).

2. Громова О.А., Торшин И.Ю., Кошелева Н.Г. Молекулярные синергисты йода: новые подходы к эффективной профилактике и терапии йоддефицитных заболеваний у беременных // РМЖ: Мать и дитя. Акушерство и гинекология. - 2011. - Т. 1.

3. Караченчев Ю.И., Гончарова О.А., Подорога Е.И. и др. Обеспеченность селеном отдельных регионов Сумской области и особенности частоты патологии щитовидной железы // Міжнародний ендокринологічний журнал. - 2013. - № 5 (53). - С. 17-20.

4. Коржинський Ю.С., Слівінська-Курчак Х.Б. Селен: біологічна роль і потреба дитячого організму // Медицина транспорту України. - 2011. - № 4.

5. Ляхнович Н.А., Гутикова Л.В. Роль йода и селена в гормональной регуляции функции щитовидной железы при беременности // Медико-биологические проблемы жизнедеятельности. - 2013. - № 2 
(10). - С. 13-23.

6. Марушко Ю.В. Роль селена в клинической практике / Ю.В. Марушко, Ю.Ю. Остапенко // Дитячий лікар. 2012. - № 5. - С. 32-36.

7. Оксилик: монография [Электронный ресурс]. Режим доступа: http://compendium.com.ua/info/200133/ print/woerwag-pharma/oksilik-antioksidantnyevitaminy-i-selen.

8. Тимків І.С. Вплив тиреоїдної дисфункції на виношування вагітності в умовах ендемічної місцевості: Автореф. дис... канд. мед. наук / Тернопільський державний медичний університет ім. І.Я. Горбачевського. - Тернопіль, 2007.

9. Хохлова Е.А. Селен и щитовидная железа: точка зрения // Новая аптека. - 2013. - № 6. - С. 82-84.

10. Шабалина Е.А., Моргунова Т.Б., Орлова С.В., Фадеев В.В. Селен и щитовидная железа // Клиническая и экспериментальная тиреоидология. - 2010. - Т. 7, № 2. - C. 7-18.

11. Becken G.l., Arthur J.R. Selenium and endocrine system // J. Endocrinol. - 2005. - Vol. 184. - P. 455-465.

12. Corvilain B., Contempre B., Longombe A.O. et al. Selenium and the thyroid: how the relationship was established // Am. J. Clin. Nutr. - 1993. - Vol. 57. - P. 244-248.

13. Demelash A., Karlsson J.O., Nilsson M., Bjorkman U. Selenium has a protective role in caspase-3-dependent apoptosis induced by $\mathrm{H}_{2} \mathrm{O} 2$ in primary cultured pig thyrocytes // Eur. J. Endocrin. - 2004. - Vol. 150. P. 841-849.

14. Drutel A, Archambeaud F, Caron P. Selenium and the thyroid gland: more good news for clinicians // Clin Endocrinol (Oxf). 2013 Feb; 78 (2):155-64. doi: 10.1111/ cen.12066.

15. Duntas L.H., Mantzou E., Koutras D.A. Effects of a sixmonth treatment with selenomethionine in patients with autoimmune thyroiditis // Eur. J. Endocrinol. 2003. - Vol. 148. - P. 389-393.

16. Gaertner R., Gasnier B.C., Dietrich J.W. et al. Selenium supplementation in patients with autoimmune thyroiditis decreases thyroid peroxidase antibodies concentrations // J. Clin. Endocrinol. Med. - 2002. Vol. 8. - P. 1687-1691.

17. Kimura T., Okajima F., Sho K. et al. Thyrotropin-induced hydrogen peroxide production in FRTL-5 thyroid cells in mediated not by adenosine 3',5'monophosphate, but by $\mathrm{Ca} 2+$ signaling followed by phospholipase-A2 activation and potentiated by an adenosine derivative // Endocrinology. - 1995. - Vol. 136. - P. 116-123.

18. Köhrle J., Jakob F., Contempre B. et al. Selenium, the thyroid and the endocrine system // Endocrinol. Rev. 2005. - Vol. 26. - P. 944-984.

19. Köhrle J. Selenium and the thyroid // Curr Opin Endocrinol Diabetes Obes. 2013 Oct; 20 (5):441-8. doi: 10.1097/01.med.0000433066.24541.88.

20. Negro R., Greco G., Mangien T. et al. The influence of selenium supplementation on postperfum thyroid status in pregnant women with thyroid peroxidase autoantibodies // J. Clin. Endocrinol. Metab. - 2005. Vol. 92. - P. 1263-1268.

21. Roman M. Selenium biochemistry and its role for human health/ M. Roman, P. Jitaru, C. Barbante // Metallomics. - 2014. - Vol. 6. - P. 25-54.

22. Selenium in the environment, metabolism and involvement in body functions / Y. Mehdi, J. Hornick, L. Istasse, I. Dufrasne // Molecules. - 2013. - Vol. 18. P. 3292-3311.

23. Schomburg L. Selenium, selenoproteins and the thyroid gland: interactions in health and disease // Nat Rev Endocrinol. 2011 Oct 18; 8 (3):160-71. doi: 10.1038/ nrendo.2011.174.

24. Tou K.A. Toulis, Anastasilakis A.D., Tzellos T.G. et al. Selenium supplementation in the treatment of Hashimoto's thyroiditis: a systematic review and a meta-analysis // Thyroid. - 2010. - № 20. P. 1163-1173.

25. Turker O., Kumanlioglu K., Karapolat I. Selenium treatment in autoimmune thyroiditis: 9-month followup with variable doses // J. Endocrinol. - 2006. Vol. 190. - P. 151-156.

26. Winther KH1, Watt T, Bjørner JB et al. The chronic autoimmune thyroiditis quality of life selenium trial (CATALYST): study protocol for a randomized controlled trial // Trials. 2014 Apr 9;15:115. doi: 10.1186/17456215-15-115.

27. Zagrodzki P., Nicol F., Arthur, J.R. Slowiaczek M. Selenoproteins in human thyroid tissues // Biofactors. - 2001. - Vol. 14. - P. 223-227.

28. Zagrodzki P., Ratajaczak R. Selenium supplementation in autoimmune thyroiditis female patient - effects on thyroid and ovarian functions (case study) // Biol. Trace Elem. Res. - 2008. - Vol. 126. - P. 76-82. 